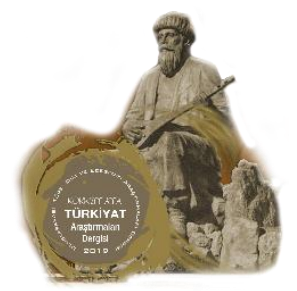

\author{
KORKUT ATA TÜRKIYYAT ARAŞTIRMALARI DERGİSI \\ Uluslararası Türk Dili ve Edebiyatı Araştırmaları Dergisi \\ The Journal of International Turkish Language $\mathcal{E}$ \\ Literature Research
}

\title{
Eski ve Orta Türkçe İki Ünlü Arasındaki -g̀- ve -g- Seslerinin Çağdaş Kirgızcadaki Durumu
}

\author{
Old and Middle Turkic Intervocalic - $\dot{g}-v e-g-$ Sounds' Situation in Modern \\ Kyrgyz
}

\section{Seçkin UYSAL*}

Öz

\begin{abstract}
Bilindiği gibi Eski ve Orta Türkçe söz içi damaksıl birincil -ġ- ve -g- sesleri Kırgızcada eriyerek düşmüş ve ikincil ünlü uzunlukları meydana getirmiştir. Bu fonetik hadise Kırgızcayı diğer Türk dilleri arasında farklı ve özel kılar. Öte yandan Kırgızcada Eski ve Orta Türkçe -g்- ve -gseslerinin -g- veya -y- sesine değiştiği bazı sözcükler de vardır. Çağdaş Kırgızcada -g-, -yseslerinin korunması bu sözcüklerdeki -ġ-, -g- seslerinin birincil olmadığını veya Kırgızca'da çok farklı bir fonetik gelişmenin daha olduğunu düşündürür. Söz içi -g- ve -y- seslerini içeren bazı sözcüklerin birincil -gं- ve -g-'ye sahip olup olmadı̆̆ı tartışmalıdır. Söz konusu sözcüklerin kökenleri incelendiğinde ise bu aykırılığın farklı fonetik gelişimlerden ziyade leksikolojik birtakım katmanlardan kaynaklandığı görülür. Kırgızların ve dolayısıyla Kırgızcanın tarihi de bu dilsel katmanları doğrulayan veriler sunar. Bu çalışmada Kırgızcada söz içinde -g- veya -y- seslerine değişmiş Eski ve Orta Türkçe -g்- ve -g- içeren sözcükler incelenerek hangilerinin arkaizm, hangilerinin Tarihî Kıpçakça katmanı veya Kıpçak ve Karluk grubu Türk dilleri katmanları oldukları ile ilgili düşünceler öne sürülmüştür.
\end{abstract}

Anahtar Sözcükler: Kırgızca, söz içi damaksıllar, Eski ve Orta Türkçe, leksikoloji.

\begin{abstract}
As well known Old and Middle Turkic primary intervocalic velars - $\dot{\mathrm{g}}$ - and -g- sounds dropped and creates secondary long vowels in Modern Kyrgyz. This phonetic phenomenon and unique feature makes Kyrgyz special and also separates it from the other Tukic languages. On the other hand Kyrgyz has some words that includes intervocalic velars - $\dot{g}_{-},-$-gthey changes -g- or -y- sounds. In this words where includes primary - $\dot{g}_{-},-$-g- velars could be mentioned that they do not have primary $-\dot{\mathrm{g}}$ - and $-\mathrm{g}$ - sounds or this results from extremely different phonetic progress. It is controversial that some words induding intervocalic - $g$ - and $-\mathrm{y}$ - have primary $-\dot{\mathrm{g}}$ - and -g- sounds. When discussed words' etymologies were investigated it has been seen that these differences come from several layers not exceptional phonetic progress. Not only history of Kyrgyz but also Kyrgyz language presents truely datas on this grammatical layers. In this study it is investigated that preserving intervocalic - $\dot{g}_{-},-$g- sounds and chaging -y- sound in Kyrgyz then mentioned which of this archaism, which of this Historical Kypchak layer and which of this Modern Kypchak and Karluk layers.
\end{abstract}

Key Words: Kyrgyz, intervocalic velars, Old and Middle Turkic, lexicology.

* Dr., Kırgızistan-Türkiye Manas Üniversitesi, Bişkek/Kırgızistan, e-posta: seckin.uysal@manas.edu.kg, ORCID: https://orcid.org/0000-0001-7315-7429. 


\section{Giriş}

Kırgızcanın tarihî tipolojik gelişimlerinden biri Eski ve Orta Türkçe söz içi damaksıl birincil - $\dot{g}_{-}$ve $-g$ - seslerinin düşmesi ve bunun neticesinde ikincil ünlü uzunluklarının meydana gelmesidir: ET. ağız > Kır. ooz "ağız", ET. ag்uz > Kır. uuz "ilk süt" , ET. yağuk > Kır. cuuk "yakın", ET. yog்an > Kır. coon "yoğun", ET. yag் > Kır. coo "düşman", ET. og̀ul > Kır. uul "oğul”, ET. ag่u > Kır. uu "zehir", ET. kaġun > Kır. koon "kavun", ET. kug்u > Kır. kuu "kuğu”, MK. ET. kagur- > Kır. koor- "kavurmak", ET. boggaz > Kır. booz "boğaz", ET. taġar > Kır. taar "dağar(c1k)", ET. yog்ur- > Kır. cuur- "yoğurmak", ET. yegen > Kır. ceen "yeğen", ET. ege > Kır. ee "sahip". Eski Türkçe sözcük köklerine eklenen yapım ekleri neticesinde iki ünlü arasında kalan - $\dot{g}$ - sesi de eriyerek ikincil ünlü uzunluğu meydana getirmiştir: ET. saġım > Kır. saam "sağım", ET. tug்ul-> Kır. tuul"doğ(ul)mak". Kırgızcada bu fonetik gelişimin görülmediği, söz içi - $\dot{g}$ - ve -g-'lerin korunduğu ya da yarı ünlü -y- sesine değiştiği sözcükler de vardır: ET. (y)a/ığaç > Kır. cıgaç "ağaç", ET. buğu> Kır. bugu "(erkek) geyik", MK. soğan > Kır. sogun "soğan", MK. tügül > Kır. tügül "değil"; ET. yigit > Kır. cigit "yiğit", MK. ögey > Kır. ögöy "üvey", ET. ögüt > Kır. ügüt "öğüt", ET. tegirmen > Kır. tegirmen "değirmen", ET bög- > Kır. bögö"suyun önünü/yolunu kesmek", bögöt "baraj"; MK. yıg்ın > Kır. cıyın "yığın", ET. ağıl> ayıl "ağıl, köy", ET. yégirmi > cıyırma "yirmi", ET. yigit ve MK. yıġın sözcüklerinde -g- ve - $\dot{g}$ seslerinin korunması Kırgızcanın uzun $i$ (ii) ve uzun $l$ (n)'ya doğru bir gelişim göstermemesi şeklindeki kısa bir açıklamayla izah edilebilir, fakat diğer sözcüklerdeki iki ünlü arasındaki - $\dot{g}_{-},-g-$ seslerinin korunması veya yarı ünlü - $y$-'ye değişmesi izaha muhtaçtır.

Kırgızcada söz içi damaksıl - $\dot{g}$ - ve $-g$ - seslerinin niçin tek tip bir gelişim göstermediğini konu edinen herhangi bir monografi bugüne kadar yapılmamıştır. Ancak ET. ve OT. dönemlerinden itibaren söz içi $-\dot{g}_{-},-g-$ damaksıllarının Çağdaş Türk dillerindeki durumlarına ve değişimlerine bazı araştırmacılar değinmişlerdir. Ramstedt (1957: 85-86) Türk dillerinde -g- sesinin sızıcılaşmaya doğru olan gelişimi ile -b- > -w- $(u$, ü) değissiminin paralel olduğunu söyler. Batı Türk dillerinde -g- sesinin -u-, $-w-$; Kuzey Türk dillerinde yarı ünlü - $y$-'ye değiştiğini ya da eriyerek ikincil uzun ünlüler oluştuğunu belirtir. Ramstedt'e göre, $-k->-g-;-k->-\dot{g}$ - ile $-g->-y-;-g->-w$ - değişimi X. ve XV. yy.lar arasında gelişmiştir. Fakat bu süreçte $-g$ - gelişimine ulaşmış lehçede $-k$-'li biçimler olacağ 1 gibi bunun tam tersi bir durum da söz konusudur. Ona göre bu düzensizlikler komşu lehçelerden alınan sözcüklere dayanır.

Söz içi damaksıllara değinen Tenişev (1984: 200-206) Eski Türkçedeki: -ag்a-, -ag்u-, -

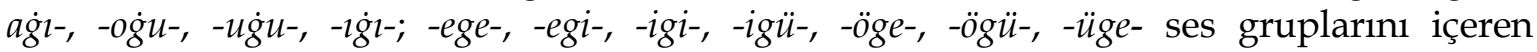
sözcüklerden örnekler vermiş, bu sözcüklerin Türk dillerindeki biçimlerini göstermiştir.

Johanson (1998: 100-101) söz içi - $\dot{g}$ - ve -g- seslerinin korunduğu, düştüğü ve dudaksıllaştı̆̆ı sözcük örnekleri sıralamış, fakat konu ile ilgili açıklama yapmamıştır.

Yılmaz (2010) Tatarca ön ünlülü sözcüklerde ünlüler arası - g- sesine dair düzensiz gelişmeleri incelediği çalışmasında; -g- sesinin dudak ünlüleri arasında - $y$-'ye değiştiğini, birincil düz ünlüler arasında veya ünlü + düz ünlü arasında ${ }^{*}$-g- sesinin korunduğunu tespit etmiş ve konuyu örnekleriyle tanıklamıştır.

Söz içi damaksılları konu edinen çalışmalardan en kapsamlısı Károly (2012)'ye aittir. Károly çalışmasında $V g V$ ve $V k V$ ses gruplarındaki değişmelerin Çağdaş Türk dillerindeki durumuna değinerek bu fonetik gelişmede $V g V$ ses grubunun gelişim şemasını şu şekilde vermiştir: $1 . g / \dot{g} \rightarrow$ dudaksıllaşma $(v) \rightarrow$ düşme $(\varnothing) ; 2 . g / \dot{g} \rightarrow$ süreklileşme/akıcılaşma $(w, y) \rightarrow$ düşme (ø). Bu çalışmada yan yana gelen ikiz (geminated) 
damaksılların (-kk-, -ḳk-; -gg-, $\left.-\dot{g} \dot{g} \dot{g}_{-}\right)$Kıpçak grubu Türk dillerindeki gelişim şeması da gösterilmiştir.

$$
\begin{aligned}
& * / \mathrm{kk} /{ }^{\mathrm{PT}}>/ \mathrm{k} />/ \mathrm{g} />/ \mathrm{\gamma} / \\
& * / \mathrm{k} / \mathrm{PT}>/ \mathrm{g} />/ \mathrm{y} / \text { Kip. } \\
& \text { */gg/PT>/g/>/ץ/Kip >/w,y/>/ø/ } \\
& \text { */g/PT>/Y/>/w,y/Kip.>/ø/ (Károly 2012: 8-10). }
\end{aligned}
$$

\section{Amaç ve Sinırlılık}

$\mathrm{Bu}$ çalışmada Kırgızcanın (Altayca ile beraber) karakteristik özelliklerinden biri olan ET. ve OT. söz içi - $\dot{g}$ - ve -g- seslerinin eriyerek ikincil ünlü uzunlukları meydana getirmesine aykırı olarak söz içi damaksılların korunduğu veya -y- sesine değiştiği sözcükler incelenmiştir. Kırgızcanın fonetik gelişimine aykırı olarak söz içinde $-g$ - ve $-y$ ünsüzlerinin varlıklarını korumasının sebebi üzerinde durulmuştur. Bu amaçla ET. ve OT. söz içi birincil - $\dot{g}_{-}$- $-g$ - seslerinin içeren sözcükler listenmiş ve bu sözcüklerin etimolojileri ile ilgili görüşlere yer verilmiştir. Söz konusu sözcüklerin sırasıyla Tarihî ve Çağdaş Türk dillerindeki durumları gösterilerek konu ile ilgili veriler derlenmiştir. Bu veriler ışığında sonuç bölümüne bir harita eklenmiş ve konuya ilişkin görüşler belirtilmiştir.

\section{Kuramsal Çerçeve}

ET. ve OT. sözcüklerdeki söz içi $-\dot{g}-$ ve $-g$ - seslerinin Kırgızcada çoğunlukla düşmesi ve bunun neticesinde ikincil uzun ünlüler meydana getirmesi yanında söz içi $-\dot{g}-$ ve -g-sesleri içeren bazı sözcüklerde bu gelişmenin görülmemesi düzensizliği Kırgızcanın tarihî gelişimi içindeki fonetik ve leksikolojik bazı hususiyetler ile ilgili olmalıdır.

$V \dot{g} V, V g V$ ses gruplarındaki düzensiz değişime fonetik açıdan bakılması söz konusu ses gruplarını içeren sözcüklerin ünlü, ünsüz nitelik ve niceliklerini akla getirir. $\mathrm{Bu}$ nedenle söz başı ve ilk hece ünlülerinin birincil ünlü içermelerinde bir düzen aranmalıdır. Fakat - $\dot{g}$ - sesinin korunduğu (AT ìgaç) Kır. cıgaç, -y- sesine değişen (AT àgill) Kır. ayıl sözcüklerinin yanında - $\dot{g}$ - ve - $g$ - seslerinin eridiği sözcüklerden ise sadece (AT

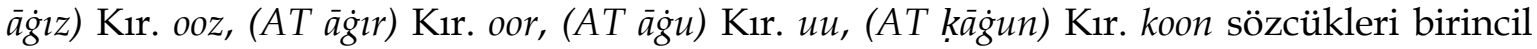
ünlü içerir. Bu durumda Kırgızcdaki bu düzensiz gelişimi birincil ünlü uzunlukları ile açıklamak mümkün değildir. Konu ünlülerin nitelikleri açısından değerlendirildiğinde de meselenin aydınlatılamayacağı hemen tespit edilebilir. Zira ET.'de Düz Ünlü $+\dot{g} / g+$ Düz

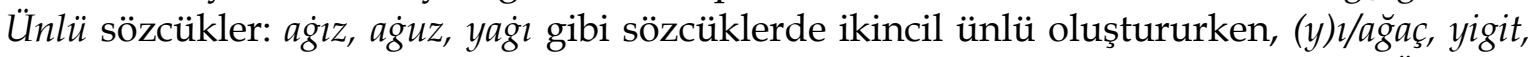
aǵll gibi sözcüklerde damaksıllar korunmakta veya $-y$ - sesine değişmektedir. Düz Ünlü $+\dot{g}$ Ig + Yuvarlak Ünlü, Yuvarlak Ünlü + g / g + Yuvarlak Ünlü söz gruplarında da durum farklı değildir. Sözcük sonlarındaki ünsüz niteliklerinin (patlayıcılık, akıcılık) söz içi damaksılların varlığını korumasına etki etmiş olma ihtimali göz önüne alınarak yapılan değerlendirme kısmi sonuçlar verse de bu durum genel olarak kandırıcı olmaktan uzaktır. Çünkü Kır. cıgaç, yigit, ügüt, bögöt sözcüklerindeki patlayıcı ç, $\mathrm{t}$ sesleri ikincil uzun ünlülerin meydana geldiği ET. ve OT. sözcüklerde görülmez. Öte yandan n, r, l gibi akıc1 ünsüz barındıran Kır. sogun, tegirmen, ögöy, cıyın, ayıl gibi sözcüklerde ya damaksıllar korunmuş ya da -y- sesine değişmiştir. ET. n, r, 1 gibi akıcı ünsüz içeren ET. yogan (Kır. coon), ET. og்ul (Kir. uul), ET. kag்un (Kır. koon), ET. tag்ar (Kır. taar), ET. yog்ur- (Kır. cuur-), ET. yegen (Kir. ceen) gibi sözcüklerde de ikincil ünlü uzunlukları meydana gelmiştir.

$V C V$ ses gruplarındaki $V^{1}, V^{2}$ ve C'ların bürünsel özellikleri için Rassadin'in Moğolcadaki $V C V$ ses gruplarının niçin tek tip gelişim göstermediği ile ilgili tasarladığ1 hipotezinin Kırgizcaya da uygulanabilirliği değerlendirilebilir. Rassadin'e göre $V V$ gelişimi $V^{1}$ ve $V^{2}$ arasındaki bürünsel farklılıklardan kaynaklanmalıdır. $V C V>V V$ 
gelişimi $V^{2}$ nin daha güçlü vurgulanmasından ortaya çıkar. Ancak eğer $V^{1} / \% /$, /ö/ gibi yuvarlak ünlüleri içeriyorsa, $V^{2}$ yi dudaksıllaştırır, ardından $C$ eriyerek $V V$ gerçekleşir. Durum böyle değilse $V C V$ ses grubu değissmeden kalır (Rassadin 1982: 38-57). Moğolca için üretilen bu hipotezi Kırgızcaya uyguladı̆̆ımızda: yog்an, og்ul, boğaz, yog்ursözcüklerinde $V^{1}$ in /o/ olduğu ve ünlü uzunluğu meydana geldiği görülür. Ancak $a \dot{g} \imath z$,

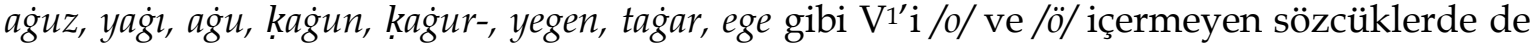
ünlü uzunluğu meydana gelmesi daha bu aşamada bile bu hipotezin Kırgızcaya uygulanamayacağını gösterir.

Kırgızca $V \dot{g} V, V g V$ ses gruplarındaki düzensiz değişimi leksikolojik açıdan değerlendirmek için - $\dot{g}_{-},-g_{-}$damaksıllarının korunduğu veya - $y$ - sesine değiştiği sözcüklerin etimolojilerine bakmak ve bu sözcüklerdeki damaksılların birincil olup olmadıklarını belirtmek gerekir. Farklı görüşlerden dolayı bug்u, tügül, bögö-t, yégirmi sözcüklerinin birincil damaksıl içerip içermemeleri tartışmalıdır. Ancak bu sözcüklerin ET. ve OT.'deki biçimleri söz içi damaksıllar içerdiklerinden bu çalışmada değerlendirilmişlerdir. Diğer sözcüklerde ise damaksılların birincil olmaları kabul görmüş gibidir. Etimolojik değerlendirme yanında söz konusu sözcükleri leksikolojik açıdan değerlendirmek Kırgızcanın Eski Kırgızca (Yenisey) döneminden itibaren gelişimi, Kırgızların diğer Türk toplulukları ile kurduğu siyasi birliktelikleri ve komşuluk ilişikleri yol gösterici olacaktır. Bu nedenle Tarihî Kıpçakça, Çağatayca, Çağdaş Kıpçak ve Karluk grubu Türk dilleri de değerlendirmeye alınmıştır.

Ramstedt'in (1957: 85-86) belirttiği Türk dillerinin başka Türk dillerinden yapmış olduğu ödünçlemeler bu düzensizliklerde rol oynamış olabilir. Bu araştırmada, hangi sözcüğün hangi Tarihi ve Çağdaş Türk dili grubundan ödünçlendiği, dolayısıyla hangi alt katmana veya yan katmana dayandığı veya hangi sözcügüun arkaizm olabileceğine dair görüşler için Károly'nın (2012) damaksıl seslerin Kıpçakça temelinde hazırladığı gelişim şeması esas alınmıştır. Konu bütünlüğünü bozmamak ve belirli alanda daha sağlıklı görüşler belirtmek amacıyla sözcüklerin yalnızca Kırgız edebî dilindeki kullanımları değerlendirilmiştir. Öte yandan bu çalışma benzer konularda yapılacak araştırmalara örnek ve öncelik teşkil edebilir.

\section{Yöntem}

Kırgızcada ET. ve OT. dönemlerinden bu yana varlığını koruyan - $\dot{g}$ - ve -g- sesleri ile bu seslerin Çağdaş Kırgızcada yarı ünlü $-y$ - sesine değişmiş biçimleri tarihî karşılaştırmalı yöntem ile incelenmiştir. Söz konusu sözcüklerin etimolojileri ile birincil ünlü taşıyıp taşımadıkları ya da $-\dot{g}$ - ve $-g$ - seslerinin gerçekten birincil olup olmadıkları ortaya konduktan sonra Kırgızcanın tarihî gelişiminin genel çerçevesi, Kırgızcanın bu fonetik özelliği ile hangi Türk dillerine yakınlaştığı ve Kırgızcada hangi tarihî dil katmanlarının olduğu verileri ortaya konmuştur.

Eski Kırgız (Yenisey) dilinin bugünkü çağdaş temsilcileri Kırgızca ve Altaycadır. Her iki topluluğun (Kırgızların ve Altaylıların) Kıpçak kabileleri ile olan siyasî birliktelikleri ve komşulukları da tarihî bir gerçektir. Kırgızcayı Hakasça, Tuvacaya yakınlaştıran fonetik özellikler de vardır (Baskakov 1969: 337). Bu dilsel ve sosyolojik yakınlıklardan dolayı sözcükler Altayca, Hakasça ve Tuvaca ile karşılaştırılmıştır.

Eski Dönem Kıpçakçaya tekabül eden (VIII. yy. sonları-XI. yy. ortaları) 922' de İbn Fadlan'ın (Kıpçak grubu Türk dili konuşan) Başkurtlardan bahsetmesi, Başkurtların ilk konuştukları dilin Kıpçakça olduğu ya da en azından Kıpçakça alt veya yan katman özellikleri taşıdığını akla getirir. Yapısında kısmen söz başı $d$ - ve $g$ - ünsüzleri bulundurma gibi Kıpçakça dışı özellikler barındırsa da Kıpçak grubu Türk dillerinden birini konuşan Karakalpaklardan bahseden XII.yy.a tarihli Rus kronikleri (Rus. Çernıye Klobuki) vardır

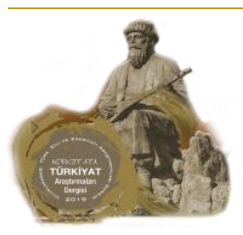


(Jankowski 2015: 271-272). Kıpçak yazı dili ile eserlerin verildiği Orta Dönem Kıpçakça XIII. yy.- XVI.yy. aralığına tarihlenir (Jankowski 2015: 271). Kıpçak dilinin en önemli eserlerinden biri XIV.da Latin alfabesiyle derlenen Codex Cumanicus'tur (Clauson 1972: xxıv). J. Eckmann (1965: 36) karışık dilli Memluk sahası eserler (1383-1400) arasında Asıl Kıpçak diline ait olanların; İrşādü'l-mülūk ve's-selațin, Gülistan Tercümesi, Bayțaratu'l-vāżih, Münyetü'l-guzāt olduğunu belirtir (Eckmann 1965: 36). Kirgiz ve Kazak topluluklarının yüzyıllar süren yakınlığı nedeniyle NE (Kuzey Doğu) ${ }^{1}$ dili olan Kırgızca Kazakça ile ortak özelliklere sahip olmuştur (Clauson 1972: xxvii-xxviii). Kırgızların Tiyan-Şan'a göçlerinin tamamlanmasının ardından doğal olarak Kırgızlar ile Uygur, Özbek, Tacik ve Kazak toplulukları arasında ekonomik ve siyasî ilişkiler meydana gelmiştir (Yunusaliyev 2016: 244).

Tarihî karşılaştırmalı yöntemde Tarihî Kıpçak dili olarak; Codex Cumanicus, İş̧ädül-mülūk ve's-selațin, Gülistan Tercümesi, Bayțaratu'l-vāżih, Münyetü'l-guzāt esas alınmıştır. Sözcüklerin seçiminde ve anlamlarında Toparlı vd.nin Kıpçak Türkçesi Sözlüğ̈̈ (2007)'ne bakılmıştır. Kırgızların Tiyan-Şan'a göçleri tamamlanmadan (XVI. yy.) bir yüzyıl önce yazı dili olmaya başlayan ve XX. yy.ın başlarına kadar bütün Doğu Türkleri arasında varlığını sürdüren Çağatay yazı dili de bu araştırmada değerlendirilmiştir. Sözcüklerin Çağatayca biçimleri için Ünlü'nün Çağatay Türkçesi Sözlüğü (2014) kullanılmıştır. Kırgızcanın Altayca, Hakasça, Tuvaca gibi Güney Sibirya Türk dilleri ile karşılaştırılması yanında Çağdaş Kıpçak grubu dilleriyle karşılaştırılmasında Başkurtça, Tatarca, Karakalpakça, Kazakça; Karluk grubu dillerle karşılaştırılmasında Özbekçe ve Yeni Uygurca esas alınmıştır. Çağdaş Kırgızca sözcükler için Yudahin'in Kırgız Sözlü̆̆̈̈̈ (1998) kullanılmıştır.

\section{Kırgızcanın Tarihi ve Tarihî Kırgızca - Tarihî Kıpçakça İlişkisi}

Yenisey döneminden (VIII. yy.) başlayıp IX.-X yüzyıllara kadar devam eden (Eski Kırgızca) (Yunusaliyev 2016: 241) Köktürk ve Uygur hâkimiyetlerinden sonra X. yy. başlangıcında Kırgız siyasi birliği oluşmaya başlamıştı. Bu Kırgız siyasi birliğinin (Kırgız Kağanlığı) altında başka halklara da hükmedildiği, bu kitlelerin içinde Kıpçakların da bulunduğu düşünülmektedir (Golden 1992: 343). Eski Kıpçakçanın VIII. yy. sonları - XI. yy. ortalarında şekillenmeye başladığı (bu dönem Erken Dönem Eski Kıpçakça olarak adlandırılır) göz önünde tutulduğunda (Jankowski 2015: 271) Eski Kırgızca ile Erken Dönem Eski Kıpçakça temasının olduğu söylenebilir. XI. yy. - 1230'lı yıllardaki Moğol istilası arasındaki dönem Geç Dönem Eski Kıpçakça olarak adlandırılır. Orta Dönem Kıpçakça XIII. - XVI. yy. aralığına tarihlenir. Genel kanıya göre Modern Türk dillerinin bağımsız olarak şekillenmelerinin başlangıcı da bu dönemden sonrasına rastlar (Jankowski 2015: 271).

Geç Dönem Eski Kıpçakça sona erip Orta Kıpçakçanın varlığını sürdürdüğü yüzyıllarda Kırgızların Tiyan-Şan'a olan göçleri tamamlanmıştı. Yunusaliyev (2016: 244) XVI. yy.dan günümüze kadar olan dönemi Yeni Kırgızca olarak adlandırmakta ve bu döneme Tiyan-Şan Dönemi demektedir. Kırgızlar Tiyan-Şan'da Uygur, Özbek, Tacik ve Kazak topluluklarıyla ilişkiler kurmuşlardır. XVI. yüzyıldan Sovyet devrimine kadar olan dönemde Kırgız sözlü edebiyat geleneği devam etmiş, ancak Kırgız edebî diliyle elimize bir eser ulaşmamıştır. Dolayısıyla Kırgız edebî dili oluşum sürecinde bölgenin yazı dili olan Çağataycanın Kırgızcaya olan etkisinden de söz etmek mümkündür.

\footnotetext{
${ }^{1}$ Kuzey Doğu grubu ile Doğu Sibirya ve komşu bölgelerde konuşulan, ancak yakın zamana kadar yazı dili olmayan diller kastediliyor (EDPT: xxvii)
} 


\section{Kırgızcanın Türk Dilleri Arasındaki Yeri}

Türk dillerini tasnif ettiği çalışmada Türk dillerini dört gruba ayıran Radloff Kırgızcayı (Kara Kırgızca) II. Batı Diyalektleri grubunda Kazakça (Kazak Kırgızca), Karakalpakça ile birlikte değerlendirmiştir (Tekin 1989: 143). Ramstedt altı gruba ayırdığ1 Türk dillerinin V. Batı grubunda (tag > taw, d > y) Kırgızcayı, Kazakça, Karakalpakça, Nogayca, Kumukça, Karaçay Balkarca, Karaimce, Tatar Mişer diyalekti ve Başkurtça ile birlikte göstermiştir (Tekin 1989: 146). Samoyloviç de Türk dillerini altı gruba ayırmıştır. Kırgızca bu altı grup içerisinde III. taw grubunda (Kıpçak, Kuzey-Batı) Altay, Teleüt, Kumandı, Kumuk, Karaçay Balkar, Tobol, Baraba, İç Rusya diyalektleri, Mişer, Başkurt, Kırım (güney kıyıları dışında), Karaim, Nogay, Kazak dil ve diyalektleri ile birlikte değerlendirilmiştir (Tekin 1989: 148). Türk dil ve diyalektlerini on iki gruba ayıran Tekin (1989: 162-163) Kırgızcayı diğer dil ve diyalektlerden müstakil olarak VIII. tōlū grubunda göstermiştir.

\section{Kırgızcanın Ünlü Fonemleri}

Çağdaş Kırgızcada sekiz kısa (a, e, 1, i, o, ö, u, ü), altı uzun (aa, ee, oo, öö, uu, üü) ünlü fonem vardır. Batmanov (1939: 38-39) Kırgızcada tek heceli (monosyllabic) uzun a (aa) fonemi olmadığını, ancak [aCa] söz grubu aralarında boşluklu iki /a/ kombinasyonunun olduğunu söyler. Ona göre /aa/ daha çok [aCa] söz grubundaki ünsüzün kaybolmasıyla oluşur: Kır. şaar, Özb. şeher; Kır. saat < saḳat < Ar. sa'at, Kır. (söyleyiş) maa < maga. Batmanov görüşünü ispat etmek için alıntı sözcükler ile teklik birinci kişi zamirinin yönelme eki aldığı biçimini örnek olarak vermiştir. Ancak Kırgızca'da aCa > aa gelişimine Türkçe sözcüklerden de örnekler verebilirdi: ET. tag̉ar > Kır. taar "dağarcık, torba" krş. Trk. söz dağarcığı, ET. saġım > Kır. saam "sağım". Bu örnekler Kırgızcada uzun a'nın (aa) fonemik olduğunu göstermektedir.

\section{Bulgular}

\section{ET., OT. -g- /-g- > Kir. -g-}

\subsection{ET. (y)a/ı̇gaç > Kır. cıgaç}

ET. ığaç (Tekin 2003: 244), TT X 417 (Nadelyayev vd. 1969: 265) > Kır. cıgaç "ağaç" (Yudahin 1998: 207), fakat sözcüğün “kütük, kesilmiş ağaç” anlamı daha yaygındır. Bitki anlamındaki ă̆aç sözcüğü için yaygın olarak Far. tarak > Kır. darak "ağaç" (Yudahin 1998: 297) kullanılır: cıgaççı(lik) "marangoz, marangozluk" (Yudahin 1998: 207). Sözcügüü 1 "aile, tohum; orman, çalı" + $\dot{g} a c ̧$ küçültme ekine dayandırılması konusunda görüş birliği var gibidir (Sevortyan 1974: 71). - $\dot{g} a c ̧$ küçültme eki konusunda Serebrennikov ve Gadjieva (2011: 98) da ayn görüştedir: ḳuş > Alt. kuş̧kaç, Tuv. kuş̧kaş "kuşcağız". ı "bitki" (Erdal 1991: 84), $\bar{\imath}$ "ağaç topluluğu, orman" (Tekin 1995: 175). Clauson (1972: 79) i iğaç "çalı ve ağaçlar" sözcügüünün XI. yy.dan önce genellikle ığaç olarak kaydedildiğini belirtmiştir.

Tarihî Kıpçakça: BV, GT, İM ag̉aç, CC ag்aç "ağaç" (Toparlı vd. 2007: 3). Çağataycada yığac/yıg்aç "ağaç" (Ünlü 2014: 1250).

Güney Sibirya Türk dilleri: Alt. agaş "ağaç, odun” (Baskakov 1947: 12), Hak. ağas “ağaç, odun" (Baskakov 1953: 16), Tuv. ıyaş "ağaç, odun; ormanlık alan" (Tenişev 1968: 434).

Kıpçak grubu Türk dilleri: Kaz. aġaş "ağaç" (Nuraliyeva 2008: 8), K. Klp. ağaş "ağaç, odun; (ahşap) kütük" (Baskakov 1958: 18), Tat. ağaç "ağaç, odun; orman (Osmanov 1966: 20), Bşk. ağas “ağaç, odun, ahşap” (Uraskin 1996: 7).

Karluk grubu Türk dilleri: Y.Uyg. yaġaç “ağaç” (Necip 1995: 454), Özb. yagaç “ağaç; orman" (Karmiyazov ve Borovkov 1941: 146).

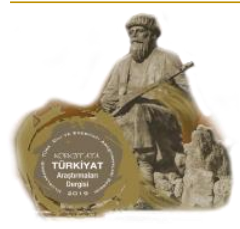


Tarihî ve Çağdaş Türk dillerinde olduğu gibi (Tuvaca hariç) Kırgızcada da söz içi

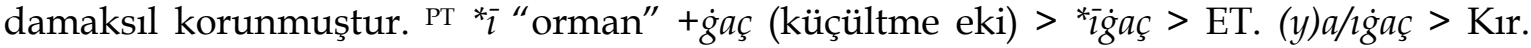
cıgaç. Sözcük sadece Kırgızca için değil burada incelenen (Tuvaca hariç) tüm Türk dilleri için arkaizm olarak değerlendirilebilir.

\subsection{ET. bugi > Kir. bugu}

ESTYa'da (Sevortyan 1978: 235-236) Kirgızca ve Kazakçada "genç erkek deve" anlamında kullanılan bugrra, bug்ur, buurcun sözcüklerinin temel anlamlarının bug்u sözcügüünden geldiği belirtilmekte birlikte, Yakutların yaşadıkları iklim ve coğrafya özelliklerinden ve deve ile aynı ekonomik işleve sahip olmasından dolayı Yakutçada "geyik" anlamında kullanıldığ1 da söylenmiştir. Kır. buurcun "genç erkek deve", Kır. buura "deve aygırı" (Yudahin 1998: 150).

buka "boğa", buġra "erkek deve", bug்u "geyik" sözcüklerinin hem ESTYa'da (Sevortyan 1978: 236-237) hem de SIGTYaL'de (Tenişev 2001: 152, 437) kökteş olabileceği üzerinde durulmuştur. ESTYa'da bug்ur / buğra'nın evcilleştirilmiş bütün büyükbaş hayvanlara verilen ad olduğu kabul edilebileceği görüşü (Sevortyan 1978: 236). SIGTYaL'de kızıl geyiklerin çıkardığı sesten hareketle yansıma kökenli bir `bug kökü tasarlanabileceği fikri ileri sürülmektedir (Tenişev 2001: 437).

Geyiklerin Ön Türkçe döneminde belirli bir bölgede (muhtemelen Doğu) evcilleştirilmiş bir türe dönüştürülmesinden sonra farklı koşullarda farklı büyükbaş hayvanları adlandırmada kullanılmış (buǵu "geyik" adının buka "boğa" ile fonetik yakınlığı ve bu hayvanların benzer ekonomik işlevlerinden kaynaklanıyor olabilir) olması da muhtemeldir (Tenişev 2001: 437-438).

Moğolların Gizli Tarihi'nde Moğ. *bugu "erkek geyik" anlamındadır. Türk. için erken dönemde Moğolcadan ödünçleme olabilir. Sözcüğün Altay paralellikleri için; TM *fegu-len "buzağ1", Türk. buka "boğa" bkz. VEWT (Räsänen 1969: 86); ESTYa (Sevortyan 1978: 237), SIGTYaL (Tenişev 2001: 152). Poppe de bug่u'nun Moğolcadan ödünçleme olduğu görüşündedir. Doerfer ise sözcüğü Moğolcada Türkizm olarak kabul eder (Sevortyan 1978: 236-237).

Tarihî Kıpçakça: CC boġa "boğa”, diğer bazı Kıpçakça eserlerde: bog̀ra/buğra "erkek deve" (Toparlı vd. 2007: 33, 36). Çağataycada buğu "erkek geyik, kızıl geyik" (Ünlü 2014: 170).

Güney Sibirya Türk dillerinde bugu sözcüğü tanıklanamamıştır. Hak.da kiik "geyik" (Baskakov 1953: 74).

Kıpçak grubu Türk dilleri: Kaz. bugı "geyik" (Nuraliyeva 2008: 43), K.Klp. bugı "geyik" (Baskakov 1958: 119). Tatarca ve Başkurtçada kullanımı tanıklanamamıştır.

Karluk grubu Türk dilleri: Y. Uyg. bugga "geyik" (Necip 1995: 52), Özbekçede kiyik (Karıniyazov ve Borovkov 1941: 218) sözcügüü tanıklanırken bugu sözcüğü taranan sözlüklerde tespit edilememiştir.

Memluk Kıpakçası, Güney Sibirya Türk dilleri ve Özbekçede bug்u biçimi tanıklanamadığından sözcük Kırgızca için arkaizm veya (Geç Dönem) Moğolcadan ödünçleme kabul edilebilir.

\subsection{MK sogan / sogiun > Kir. sogon}

soǵan / sog்un MK I 409 (Nadelyayev vd. 1969: 506-507) > Kır. sogon “soğan". Sözcügünn kökeni ile ilgili iki temel görüşten birincisi L. Bugadov'a aittir (Bud. II 404). Ona göre sözcük sok- "sokmak, içine yerleştirmek" kökünden gelir. Rassadin de aynı görüşü

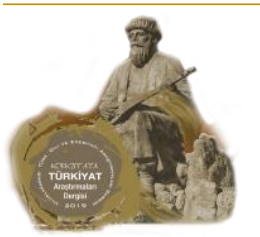


benimsemiştir. VEWT, 425a ve Brock. OGM § 53'te sog̀an / soġun'un soy- "soymak" eylem kökünden geldiği görüşü vardır (Levitskaya vd. 2003: 296-297).

soğan'ın soy- "soymak" eyleminden geliştiği görüşüne Doğu Türkçesindeki -GAn ortaç ekinin varlığ1 ile itiraz edilebilir. Borcklemann'ın soġan < soy-ġan görüşü kabul edilirse Çağataycada ya da Çağataycanın devamı olan dillerin birinde veya birkaçında *soyǵan/soygan biçimi görülmeliydi. Üstelik Doğu Türkçesinde soy- "hayvan kesmek/boğazlamak; hayvan derisi yüzmek" anlamındadır [krş. çeç- "düğüm çözmek, soymak, kıyafet çıkarmak; problem çözmek" (Yudahin 1998: 257)].

L. Bugadov'un sok- "sokmak, içine yerleştirmek" köküne dayalı görüşü ( ${ }^{*}$ soḳ-ḳan $>$ *sokg̣an > soġan) ikiz ünsüzleşmesi (consonant gemination) açısından kabul edilebilir görünse de *sokan biçiminin tanıklanmamasından, yani bu biçimde bir söz kalıntısı olmamasından dolayı bu açıklama kandırıcı olmaktan uzaktır. Sözcük *su-ġan (<su-

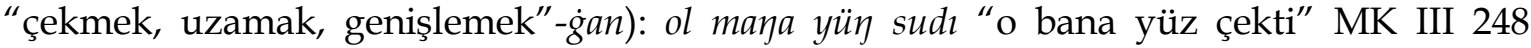
(Nadelyayev vd. 1969: 512) gelişmiş olmalıdır. Dolayısıyla söz içi damaksıl -ǵg- birincildir.

Sözcügüun Sans.dan alıntı olduğu görüş de vardır: sukanda सुकन्द su "iyi, kıymetli" + kanda "yumru kök" etimolojturkce.com/kelime/sogan (Erişim Tarihi: 04.06.2021).

Tarihî Kıpçakça: CC, BV, GT soğan "soğan" (Toparlı vd.: 238). Çağataycada soġan “soğan” (Ünlü 2014: 997).

Güney Sibirya Türk dilleri: Alt. sogon "soğan sapı" (Baskakov 1947: 129), Hak. soġan "soğan, soğan sapı" (Baskakov 1953: 191), Tuv. soguna "soğan, soğan sapı" (Tenişev 1968: 271).

Kıpçak grubu Türk dilleri: Tat. sugan "soğan" (Osmanov 1966: 488), Bşk. hugan "soğan" (Uraskin 1996: 741). Sözcük Kazakça ve Karakalpakçada tanıklanamamıştır. Bu dillerde soğan anlamında piyaz sözcügü kullanılır: Kaz. piyaz (Nuralieyeva 2008: 155), K.Klp. piyaz "soğan" (Baskakov 1958: 534). Kur.da da piyaz "soğan" (Yudahin 1998: 623) aktif olarak kullanılır.

Karluk grubu Türk dilleri: Y. Uyg. soġan "soğan" (Necip 1995: 357). Sözcük Özbekçede tanıklanamamıştır.

Sözcüğün tartışmalı kökeni dışında hem ET., OT., Tarihî Kıpçakça ve Çağataycadaki kullanımı (soġan) bilindiğinden hem de soğan anlamında aktif olarak Far. piyaz sözcügünün kullanılmasından dolayı bu biçim Kırgızca için arkaizm kabul edilebilir.

\subsection{MK. tügül > Kir. tügül}

Ramstedt tegül (tökel) sözcügünün töke- "bitmek, tüke-/-t-/-n- eylemi ile -l e.a.y.e.den geldiğini düşünür (Ramstedt 1924: 213), (Sevortyan ve Gadjieva 1980: 214).

A. von Gabain tegül'ün tek $+o l$ (*yok $+o l>$ yog்ul)dan (analoji ile) geldiği görüşündedir. (Gabain 1952: 86-87), (Sevortyan ve Gadjieva 1980: 214).

Kononov tegül / degül'ü MK'nin Argu dilinden verdiği olumsuzluk ifadesi örneği "dag̉ ol" ile açılkar (bkz. Broc. OGM § 143; Nadelyayev vd. 1969: 645), krş.: MK III ol andag் dag் ol "(o) öyle değil" (Nadelyayev vd. 1969: 158). Kononov'a göre değil / dag்ol, dag் + ol biçiminden meydana gelmiş birleşik sözcüktür; dak + ol (işaret zamiri): değil (не есть, не) "yok" anlamı taşır. Ancak dag் ol görüşünde söz başı $d$ - ünsüzü ile söz içi - $a$ - ünsüzünü açıllanmaya muhtaçtır (Sevortyan 1980: 214).

Tarihî Kıpçakça: Sözcüğün Asıl Kıpçakça olarak değerlendirildiği eserlerde $d$-'li olması ilgi çekicidir. degül (BV, GT, İM); devül (CC); dögül "değil" (GT, MG) (Toparlı vd.

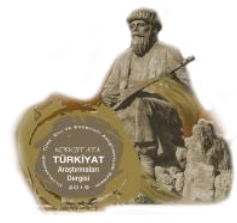


2007: 58, 60, 64). Diğer metinlerde: tegil (DM), tegül (KK, RH); tögül (MG); tüyül (TZ) "değil” (Toparlı vd., 2007: 58, 60, 64). Çağataycada tügül “değil” krş. digül, dögül, tögül, degil, degül (Ünlü 2014: 278).

Güney Sibirya, Karluk grubu Türk dillerinin hiçbirinde tanıklanmayan sözcük, Kıpçak grubu Türk dillerinde ise sadece Başkurtçada tanıklanmıştır: Bşk. tügel "değil" (Uraskin 1996: 649).

Orh. T. ve E. Uyg.da görülmeyen sözcük ESTYa'da (Sevortyan 1980: 214) açılklandığ 1 gibi $t e k+o l$ veya dag்+ol biçimlerinden gelişmiş olmalıdır. Tarihî Kıpçakça metinlerindeki degül (BV, GT, İM), dögül (GT, MG), tegül (KK, RH), tögül (MG), tüyül (TZ) "değil" (Toparlı vd. 2007: 58, 64, 268, 282) kullanımlarda bu görüşü destekler. Bu yapılar XIII. ve XIV. yy.lardan sonra ortaya çıkmış olmalıdır.

Kırgızcada değil anlamında aktif olarak emes (<er+mes) sözcüğünün kullanılması göz önüne alındığında tügül arkaizm olarak kabul edilebilir.

\subsection{ET. yigit > Kir. cigit}

W. Bang sözcüğ ü "alpag̉ut, bayaġut" sözcükleri ile karşılaştırarak yi-/ye- "yemek" eylemlerine dayandırır ve bunu -git ekli bir türemiş sözcük kabul eder. Sözcügüun yig, yeg "daha iyi" + it şeklinden de gelişebileceğini belirten görüşler de vardır (Brock. OGM § 59), (Sevortyan ve Levitskaya 1989: 199). Sözcük ile ilgili bir diğer görüş de *(y)igi- "beslemek" eylem kökünden - $t$ eylemden ad yapma ekine dayanan görüştür. yigit'in sadece insanlar için değil diğer canlılar için de kullanılması bu etimolojiyi destekler: igid öküz "buzağı" MK III 16, Bodr. Ișf. A. 38 (Nadelyayev vd. 1969: 205). *yig/yeg kökü yegin ve yegit, tegin ve tegit'te olduğu gibi birlik-çokluk bağlantılı biçimleri olabilir (Nadelyayev vd. 1969: 547$548)$.

BV, GT, IM, MG yigit, CC igit (Toparl1 vd. 2007: 322), CC yegit "yigit" (Toparlı vd. 2007: 317). Çağataycada yigit “yiğit, genç, delikanlı” (Ünlü 2014: 1253).

Güney Sibirya Türk dilleri: Alt. d'iit "delikanlı, genç" (Baskakov 1947: 54), Hak. çiit “delikanl1, genç" (Baskakov 1953: 316).

Kıpçak grubu Türk dilleri: Kaz jigit "delikanlı; dost" (Nuraliyeva 2008: 83), K.Klp. jigit "delikanlı" (Baskakov 1958: 250), Tat. yeget "delikanll, cesur; damat; talip (konuşma dili)" (Osmanov 1966: 144), Bşk. yeget “delkanlı, genç; damat" (Uraskin 1996: 177).

Karluk grubu Türk dilleri: Y. Uyg. jigit / yigit "yiğit, delikanlı" (Neci 1995: 182, 468), Özb. yigit “delikanlı" (Karıniyazov ve Borovkov 1941: 195).

Alt. ve Hak.daki uzun i (ii)'li biçimler, cigit'in arkaizm veya Kıpçak, Karluk yan katmanı olduğunu düşündürür.

\subsection{MK. ögey > Kir. ögöy}

ögey 'üvey' fonetik değişmeler ile Kuzeydoğu'da öy/üy biçimleri görülür, ögey anamız ,"üvey annemiz" Uyg. VIII., ögey kizz “üvey kız” Kaş I 123 Kıp. ögey og̉lan "üvey oğlan" (Clauson 1972: 119).

Räsänen (1949: 120) Türk. ögey "üvey, öz olmayan" ile Moğ. ügey "değil, hayır" sözcüklerinin karşılaştırır. Doerfer ise Türk. ögey ile Moğ. ügey'in hem morfolojik hem de fonetik açıdan karşılaştırılamayacağı görüşündedir (Doerfer 1967: 160).

Sözcük *ög / *ök "anne" +key ya da +ey (küçültme ekleri) eklerinden biri ile oluşmuş gibi görünmektedir. +key küçültme eki ile oluşmuş biçimin ikiz ünsüzlü (geminated) olması da fonetik açıdan uygundur: ögey "annecik, anne yerine geçen ?" < 
*ög-gey < *ög+key. +kay / +key küçültme eki ile ilgili diğer örnekler: kuyan "tavşan" > Tat. kuyankay "tavşan yavrusu", båla > Özb. bålakay "çocukcağız" (Serebrennikov ve Gadjieva 2011: 97).

+ey küçültme ekli biçimi: ögey "annecik, anne yerine geçen?" < ög "anne" +ey biçiminde tasarlanabilir. +ay/+ey küçültme eklerine dair diğer örnekler: ata > Nog. atay "babacık", Özb. båba > båbay “dedecik" (Serebrennikov ve Gadjieva 2011: 98).

Tarihî Kıpçakçada Asıl Kıpçakça olmayan eserlerden birinde tanıklanmıştır: ögey "öz olmayan" (TA) (Toparlı vd.: 209).Çağataycada ögey "üvey, öz olmayan akrabalık" (Ünlü 2014: 872).

Güney Sibirya Türk dilleri: Alt. ööy / öy "üvey" (Baskakov 1947: 118-199), Hak. ööy "üvey" (Baskakov 1953: 136). Sözcük Tuvacada tanıklanamamıştır.

Kıpçak grubu Türk dilleri: Kaz. ögey “üvey” (Nuraliyeva 2008: 148), K. Klp. ögey "üvey" (Baskakov 1958: 504), Tat. ügi “üvey; yabancı” (Osmanov 1966: 745), Bşk. ügey "üvey" (Uraskin 1996: 685).

Karluk grubu Türk dilleri: Y. Uyg. ögey "üvey" (Necip 1995: 304), Özb. o'gay “üvey” (Karıniyazov ve Borovkov 1941: 625).

Hem Tarihî hem Çağdaş Türk dillerindeki veriler Károly (2012: 11)'nın ikiz ünsüzlü (geminated) şemasına göre değerlendirildiğinde sözcük Kıpçakça katmanı olarak değerlendirilebilir.

*/gg/PT> /g/ > / / / Kip. > /w,y/ > /ø/ = *ök/ög-ey > öggey > ögey > Kir. ögöy krş. Alt. ööy /öy "üvey” (Baskakov 1947: 118-199), Hak. ööy “üvey” (Baskakov 1953: 136).

\subsection{ET. ögüt > Kır. ügüt}

ET. ögüt “öğüt” UKD 37/6, ögüt al- “öğüt almak” MK I 440, ögüt ber- “öğüt vermek" KB 29/16 (Nadelyayev vd. 1969: 382), -g-'nin birincil olup olmadiğ1 kesin değildir: ögüt < *ög- / ök- "düşünmek"+ -üt. Ramstedt'e göre: ö-güt (<öğür-t- “öğüt vermek, tavsiye etmek") (Sevortyan 1974: 501). EDPT (Clauson 1972: 102), SIFTYaF (Tenişev 1984: 195) ve OTWF'de (Erdal 1991: 343) sözcük ö- "düşünmek; hatırlamak" eylemine dayandırılmıştır.

Tarihî Kıpçakça: GT ögüt “ögüut, tavsiye” (Toparlı vd. 2007: 209). Çağataycada ögüt “öğüt, nasihat” (Ünlü 2014: 872).

Sözcük Güney Sibirya Türk dillerinde tanıklanamamıştır.

Kıpçak grubu Türk dilleri: K. Klp. ügit “ikaz” (Baskakov 1958: 687), Tat. üget “öğüt, ikaz" (Osmanov 1966: 744), Bşk. ögöt "öğüt” (Uraskinn 1996: 478).

Karluk grubu Türk dilleri: Y. Uyg. ögüt “öğüt, nasihat” (Necip 1995: 304). Sözcük Özbekçede tanıklanamamıştır.

Sözcük Tarihî Kıpçakça, Kıpçak grubu Türk dilleri ve Y.Uyg.da da Kırgızcada olduğu gibi -g-'lidir. Sözcüğün Güney Sibirya Türk dillerindeki (uzun ünlülü) biçimi tanıklanabilseydi sözcük arkaizm veya Kıpçakça katmanı olarak nitelendirilebilirdi. Kıpçak grubu Türk dilleri ve Y. Uyg.daki biçimler sözcüğün bu dillere ait yan katman özelliği olduğunu düşündürüyor.

*/k/PT > /g/ > / / Kip. (Károly 2012: 11) = *ög/ök- “düşünmek" - üt >ögüt (V *öküt)> örüt $($ ögüt $)>$ Kir. ögöt. 


\subsection{ET. tègirmen > Kir. tegirmen}

tégirmen MK. III 282, 355 (Nadelyayev vd. 1969: 548) > Kır. tegirmen "değirmen". Sözcük kökü için tegir- (teg-ir-), tegür- (teg-ür-), teger (teg-er-) (Sevortyan 1980: 177) ya da ad biçimi tegre: tegir- "etrafını çevirmek" (tegir "etraf), tegür- ( < teg- "değmek, uzamak" (Clauson 1972: 485) etimolojilerine göre *teg- kökü genel kabul görmüş gibidir. Erdal ET tegirmi "yuvarlak, daire, etrafı çevrili" (Suv. 212/5) (Nadelyayev vd. 1969: 538) köküne bağlanabileceği görüşünde olmakla beraber /-mI/ ekinin belirsizliğini de belirtir. Buradaki -mi eki ile İstemi (iste- "aramak" + -mi) sözcügüündekinin bir ve ayn olabileceğini de belirtir (Erdal 1991: 389). Sözcükle ilgili olarak DTS'de (Nadelyayev vd. 1969: 551) teๆ"yükselmek, kalkmak" -ir biçiminde bir açıklama yapılmıştır.

Yukarıdaki açıklamalara ek olarak sözcüğün kökeni ile ilgili teg- "değmek; dönmek"-gir "ettirgenlik eki" (tegir- "değmek; döndürmek") biçimi de tasarlanabilir. Orh. T. ve E. Uyg.de kullanılan -GUr ettirgen çatı eki bu görüşü destekler: kigür- "sokmak", odgur- "uyandırmak", tirgür- "diriltme" (Tekin 2003: 94); amırtg்ur- "teskin etmek", azg்ur"azdırmak" (Gabain 2007: 59).

Tarihî Kıpçakça: GT, CC tegirmen “değirmen” (Toparlı vd. 2007: 268). Çağataycada tégirmen "değirmen" bkz. tigirmen, tigirmin (Ünlü 2014: 1100).

Güney Sibirya Türk dilleri: Alt. teermen "değirmen” (Baskakov 1947: 146), Hak. teerben "değirmen" (Subrakova 2006: 607), Tuv. deerbe "değirmen” (Tenişev 1968: 138).

Kıpçak grubu Türk dilleri: Kaz. diyimen "değirmen” (Nuraliyeva 2008: 56), K. Klp. digirman "değirmen" (Baskakov 1958: 171), Tat. teğ̌rmen "değirmen" (Osmanov 1966: 526). Sözcük Başkurtçada tanıklanamamıştır.

Karluk grubu Türk dilleri: Özb. tegirmen "değirmen” (Karıniyazov ve Borovkov 1941: 444). Sözcük Yeni Uygurcada tanıklanamamıştır.

Hem Güney Sibirya Türk dillerindeki /-g-/ > /ø/ gelişimi hem de PT'deki */gg/ikiz ünsüzlüleşmesinden (geminated) dolayı sözcüğün arkaizm ya da Kıpçakça katmanı olduğu söylenebilir. ${ }^{*} / \mathrm{gg} />/ \mathrm{g} />/ \mathrm{\gamma} / \mathrm{Kip} .>/ \mathrm{w}, \mathrm{y} />/ \varnothing /={ }^{*}$ teg-gir-men $>$ Kir. tegirmen.

\subsection{ET bög- > Kir. bögö-}

ET. bög- “(insan veya nesne) biriktirmek, bir araya getirmek, toplamak anlaminda Çağdaş Türk dillerinde "su biriktirmek, baraj oluşturmak" anlamlarında NC (Kuzey Doğu)'de Kır. bögö-, Kaz. böge- biçiminde yaşar. Clauson'a göre böge- biçimi OT. döneminden sonra ortaya çıkmış olmalıdır: Suv. 137,4: türe böge "(bütün) günahlarımın toplamı"; MK II 19: ol su:vuğ bögdi "suyu bir havzada/barajda topladı" (Clauson 1972: 324).

ESTYa'da (Sevortyan 1978: 209) *bög, *böv, *böy kökteş sözcüklerin tamaminda "su biriktirme, baraj oluşturma" anlamlarının geçerli olduğu belirtilir. Türk dillerinde söz ünsüzü farklılık gösteren (-g, -k gibi) tek heceli gövdeler vardır: bög/bök, bög-/bök- ve ayrıca bek. Bu gövdeler muhtemelen $-k /-k ;-\dot{g} /-g$ ekleriyle türetilmişlerdir. Bu kökteş (homoform) sözcüklerden bög ad soylu sözcükten böge- eylemi türemiştir.

Ramstedt, KWb'de sözcüğün Moğ. bögvle (<*bög)'yi ad köküne dayandırarak Türk. biçimlerle karşılaştırılabileceği görüşündedir (Ramstedt 1935: 54b). ESTYa' da (Sevortyan 1978: 166) da Türk. bög, Moğ bög' ün anlamsal yakınlığ1 (suyu biriktirme, baraj oluşturma) sözcüğün Türkçe ve Moğolca için ortak söz varlığına ait olabileceğini düşündürmektedir. 
Tarihî Kıpçakçada sadece CC'de bögey- "boyun eğmek, itaat etmek" (Toparlı vd.: 35) sözcüğü tanıklanmıştır. Çağ.da bögütle- "bağlamak, akarsuyun önüne set çekmek" (Ünlü 2014: 167).

Sözcüğün Türk dillerindeki türemiş biçimler.

a) bög-e (e.a.y.e) $\rightarrow$ Kur. bögöt ve Kaz. böget "baraj”

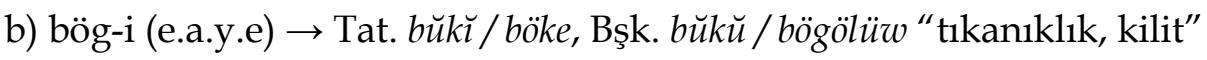

c) böge-'den (veya bög-'den)- (X)t e.a.y.e. Kaz., K.klp., Trk diyal. böget DS II 263 (Sevortyan 1978: 210).

Güney Sibirya Türk dilleri: Alt. bökö- “bükmek, eğmek” (Baskakov 1947: 34). Sözcük Hakasça ve Tuvacada tanıklanamamıştır.

Kıpçak grubu Türk dilleri: Kaz. böget "baraj; su rezervi, depo" (Nuraliyeva 2008: 42), K. Klp. böget "baraj” (Baskakov 1958: 116), Tat. böke "tıkanıklık" (Osmanov 1966: 92), Bşk. bögölöw "bükmek" (Uraskin 1996: 101).

Altaycada görülen -k-'li biçim ve CC'deki bögey- "boyun eğmek, itaat etmek" (Toparlı vd. 2007: 35) kullanımı ve Kıpçak grubu Türk dillerinde /w,y/li biçime rastlanılmaması sözcüğün bük- "bükmek, eğmek" köküne dayanabileceğini düşündürmektedir. $/ k /$ nin birincil olma durumuna göre sözcük Kıpçakça katmanı olmalıdır: */k/PT > /g/ > / / / Kıp. = *bük-/bök-et ? > büget-/böget- > Kır. bögöt.

\section{ET., OT. - $\dot{\mathrm{g}}-/$-g- > Kir. -y-}

\subsection{MK. yig̀in > Kir. ciyın}

MK III 22 yıg่ın > cıyın "yığın, küme; toplam". Sözcük yık- / yıg- eyleminin hem geçişli hem de geçişsiz eylem olma özelliği yanında Y. Uyg. Diyal. yıkıl- "yıkılmak, düşmek" ile beraber yıkıt- "yık(tır)mak, düşürmek" gibi bir biçimin görülmesi de ilginçtir (Sevortyan ve Levitskaya 1989: 270-271). EDPT'deki (Clauson 1972: 904) gibi yıg்- kökünü esas alan Ramstedt, KWb'de sözcüğü Moğ. juga-, joga-, jigu- "toplamak" sözcüğü ile de karşılaştırır (Ramstedt 1935: 477a).

-kın eki kendi türevleriyle birlikte genetik bakımdan -kan ekine akrabadır, ondan ancak ünlüler ile ayrılır: tut- "tutmak" > Kır. tutkıı "esir, tutsak", uç- "uçmak" > Özb. uçkun "kıvılcım" (Serebrennikov ve Gadjieva 2011: 100). -kın ekinin meydana getireceği ikiz ünsüz (geminated) olma durumu sözcük için geçerli olabilir: * $y \imath k-$ / yıg- $+-k ı n ~>$

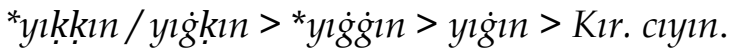

Tarihî Kıpçakça: cığıl-, cıkııl-, cıhıl- "yıkılmak, devrilmek” (CC) (Toparlı vd. 2007: 42); yıkıl- "yıkılmak, devrilmek" (CC, GT, IM, MG) (Toparlı vd. 2007: 320). Ayrıca yık“yıkmak, harap etmek" (BV, GT, vd.) (Toparlı vd. 2007: 320).

yığ- "yı̆̆gmak, biriktirmek, toplamak" (GT) (Toparlı vd. 2007: 320), yıy- (TZ) Toparlı vd. 2007: 322), cıy- (CC), cıv- (CC) “yığmak, toplamak" (Toparlı vd. 2007: 43). Çağataycada yığın “yığın, küme, topluluk, kalabalık, izdiham; saldırış” (Ünlü 2014: 1250).

Güney Sibirya Türk dilleri: Alt. d'ık- "yıkmak, yere atmak" krş. d'ıgın "kesilmiş ağaç, yığın" (Baskakov 1947: 60-61), Hak. çıg்- [çırğa] "toplamak, yığmak" krş. çığıl“yıkılmak" (Baskakov 1953: 325). Sözcük Tuvacada tanıklanamamıştır.

Kıpçak grubu Türk dilleri: Kaz. jıgu “yıkmak, devirmek" (Nuraliyeva 2008: 81) krş. jiyıntık "koleksiyon, toplam", jiyın "toplamı" (Nuraliyeva 2008: 76), K. Klp. jık- "yıkmak, yere atmak; devirmek" (Baskakov 1958: 273) krş. jıyıw "toplam", jıy- "toplamak, biriktirmek" krş. jık- "yıkmak, devirmek" (Baskakov 1958: 273), Tat. yıgıluw "yıkılmak,

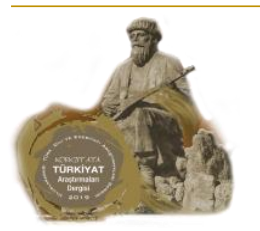


düşmek", yıguw "yıkmak, dökmek" (Osmanov 1966: 144, 145), Bşk. y̆ğğlı̆w "teçhizat,

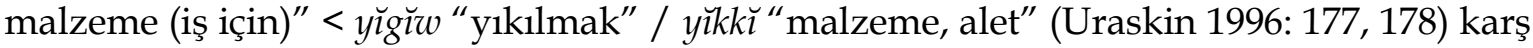
yıyın "yı̆̆ın, biriktirme; toplantı" (Uraskin 1996: 240).

Karluk grubu Türk dilleri: Y. Uyg. yig̈im "toplam" (Necip 1995: 468) jig̈in / yig̈in "yığın, küme; kalabalık, meclis" (Necip 1995: 182) krş. yékilmak "yıkılmak" (Necip 1995: 464), Özb. yikilmak "yıkılmak" (Karıniyazov ve Borovkov 1941: 198) krş. yigìn "toplam" (Karıniyazov ve Borovkov 1941: 199).

Tarihî ve Çağdaş Türk dillerindeki veriler $/ k /$ ile $/ \dot{g} /$ nin fonemik farkını açıç̧a göstermektedir. Dolayısıyla yık- "yıkmak, harap etmek" ile yıǵ- "yı̆ğmak, toplamak" eylemleri kökteş değildir.

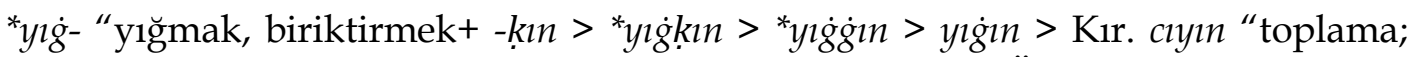
toplantı" (Yudahin 1998: 214). Alt. d'ıgın, Y. Uyg. jigin / yig̈in, Özb. yig̈in biçimlerinin aksine Kıpçak grubu Türk dillerinde $-\dot{g}->-y$ - değişimim tamamlanmış görünmektedir. CC.'deki cıy-, cıv- biçimleri de bu değişimim henüz XII. veya XIII. yy.larda başladığının kanıtıdır. Buna göre Kır. cıyın Tarihî Kıpçakça veya Kıpçak grubu Türk dilleri katmanı olarak kabul edilebilir.

\subsection{ET. ag̀ıl > Kır. ayıl}

ET. ag்ıl E 47/5, Th S11/71 (Nadelyayev vd. 1969: 18) > Kır. ayıl “köy" . Sözcük *āg/ ${ }^{*} a \dot{g}-/{ }^{*} a w-+-(a) l$ (yer adlar1 yapan ek) (Sevortyan 1974: 84). Clauson NE (Kuzey Doğu) ve NC (Kuzey Merkez) dillerindeki ayıl biçiminin Moğolca'dan tekrar ödünçleme olduğu görüşündedir (Clauson 1972: 83). Doerfer Türk. ag்ıl biçiminin Moğ. ayil biçiminden daha eski olduğunu belirterek: Türk. ag்ıl > Moğ. ${ }^{*} a \dot{g} \imath l>{ }^{*} a g i l>$ ayil fonetik gelişimini göstererek Türk. ağıl > Moğ. ayil gelişimini doğru bulmaz. Doerfer (1967: 84)'e göre Far. şehir, Sogd. kent gibi yerleşim adları çoğunlukla yerleşik topluluklardan ödünçlemedir.

Tarihî Kıpçakçada: CC, BV, GT, MG'de sözcük tanıklanamamıştır. Yalnızca KFT ve Kİ'de $a \dot{g} \imath l$ "ağıl, koyun ve keçi sürelerinin gecelediği çitle çevrili alan" (Toparlı vd. 2007: 3) biçiminin olması en azından XVI. yy.a kadar awıl veya awul (belki de ayıl) gelişiminin olmadığı gösterir. Çağataycada ayıl "mandıra, ahır" bkz. ağıl, avul, avıl (Ünlü 2014: 72, 73, 77).

Güney Sibirya Türk dillerinde: Alt. ayıl "aile (ayıl-d'urt); çadır; köy" (Baskakov 1947: 15), Hak. aal "yerleşim bölgesi / alanı, köy; kırsal bölge" (Baskakov 1953: 12), Tuv. aal "yerleşim alanı, köy; ev" (Tenişev 1968: 6).

Kıpçak grubu Türk dilleri: Kaz. avıl "köy" (Nuraliyeva 2008: 64), K. Klp. awıl "köy" (Baskakov 1958: 64), Tat. avıl "köy" (Osmanov 1966: 20), awıl "köy, yerleşim bölgesi" (Uraskin 1996: 57).

Karluk grubu Türk dilleri: Y. Uyg. avul "köy" (Necip 1995: 23), Özb. åvul "köy" (Karıniyazov ve Borovkov 1941: 305).

Altayca ve Tuvacadaki uzun $a^{\prime} l_{1}$ biçimler (aal) ile Kıpçak grubu dillerin $/ \dot{g} />/ v, w /$ değişimine ulaşmış biçimlerin aksine Kırgızcada /y/li biçimin görülmesi sözcüğün Kıpçakça katmanı değil Moğolcadan tekrar ödünçlenme olduğunu ihtimalini kuvvetlendirmektedir.

\subsection{ET. yėgirmi > Kır. cıyırma}

ET. yégirmi E 11/1, KT 6/11 (Nadelyayev vd. 1969: 253) > Kir. cıyırma "yirmi". Etimolojisi net olmayan sözcüklerden biridir. Sözcükle ilgili dikkate değer iki görüşten biri Ramstedt'e aittir. Ona göre sözcük Moğ. *jigür-, *jigir- "çift olmak" eylemlerine

Korkut Ata Türkiyat Araştırmaları Dergisi
Uluslararası Türk Dili ve Edebiyatı Araştırmaları Dergisi
The Journal of International Turkish Language E Literature Research
Sayı 5/ A ğustos 2021


dayanabilir. Sözcük ile ilgili diğer görüş Bang'a aittir. O ise sözcügüun *ikir "iki gövde" anlamina gelen soyut ad köküne bağlar (Sevortyan ve Levitskaya 1989: 201).

Tarihî Kıpçakça: BV, GT, İM yigirmi “yirmi” (Toparlı vd. 2007: 322). Çağataycada yigirmi "yirmi" krş. yégirmi, igirmi, igirme (Ünlü 2014: 1253).

Güney Sibirya Türk dilleri: Alt. d'irme "yirmi" (Baskakov 1964: 124), Hak. çib̆̌rgi "yirmi" (Baskakov 1953: 315), Tuv. çeerbi “yirmi” (Tenişev 1968: 399).

Kıpçak grubu Türk dilleri: Kaz. jiyırma “yirmi” (Nuraliyeva 2008: 76), K. Klp. jigirma "yirmi" (Baskakov 1958: 250), Tat. y̆̊̆ğrme "yirmi" (Osmanov 1966: 144), Bşk. yı̆ğ̌rme "yirmi” (Uraskin 1996: 177).

Karluk grubu Türk dilleri: Y. Uyg. jigirme / yigirme "yirmi" (Necip 1995: 182, 468), Özb. yigirma "yirmi” (Karaniyazov ve Borovkov 1941: 195).

Diğer Türk dilleri ile karşılaştırıldığında Güney Sibirya Türk dillerindeki biçimlerin farklı bir fonetik gelişim gösterdikleri söylenebilir. Kıpçak ve Karluk grubu dillerde /g/nin korunması bu diller için arkaizm sayılabilir. Kaz. jiyırma, Kırgızca cıyırma biçimleri sözcüğü burada incelenen diğer tüm dillerden ayırır. cıyırma biçiminin Kazakça yan katman olma ihtimali yüksektir.

\section{Sonuç}

ET. ve OT. iki vokal arası - $\dot{g}_{-},-g$ - seslerini içeren bazı sözcüklerin Kırgızcada niçin erimediğini ve ikincil uzun ünlü oluşturmadığını tam anlamıyla tespit etmek, başka bir deyişle bu sürecin ne zaman ve ne şekilde kural dışı hâle geldiğini belirlemek için ET. ve OT. -g'-, -g- seslerini içeren söz gruplarının fonetik özelliklerine, sözcüklerdeki ünlü ve ünsüz niteliklerine bakmak gerekir. bugu, sogon, tügül, ögöy, ögöt, clyırma, cıyın sözcüklerinin kök veya gövdelerinde gerçekten birincil $-\dot{g}_{-},-g_{-}$ünsüzleri taşıyıp taşımadıkları bu sözcüklerin etimolojileri incelendiğinde görülmüştür. Kırgızcada iki vokal arası - $\dot{g}-,-g$ - seslerinin tamamının eriyerek düştüğ ü, istisnaî sözcüklerin ise aslında $k_{-}^{-}>-g_{-},-k->-g-$ gelişiminin tamamlanmış biçimi olduğu şeklinde bir izah sözcüklerin birincil $-\dot{g}_{-},-g-$ taşıyıp taşımaları tartışmasından ve bu sözcüklerin bir kısmının Altay, Hakas ve Tuva yazı dillerinde ikincil uzun ünlülü olmasından dolayı kandırıcı olmaktan uzaktır. Özellikle X.-XII. yy.lar arasındaki süreçte Kırgızca ile Altaycanın tipolojik benzerliklerinin bozulmaya başladığı gerçeği unutulmamalıdır. Bu açıdan konuya tekrar fonetik açıdan bakmak faydalı olacaktır.

Söz konusu sözcükleri leksikolojik açıdan incelediğimizde ise daha kandırıcı sonuçlar elde etmek mümkündür. Tarihî ve Çağdaş Türk dil ve diyalektlerinden yapılan ödünçlemeler Kırgızcanın fonetik gelişim sürecinde istisnalar oluşturmuş olabilir. Zira birçok dil eski diyalekt sürecinin dallanması sonucu ortaya çıkmıştır. Bu nedenle yazı dillerinin hemen hemen tamaminda karışık "isogloss"lar bulunması normaldir. Diyalektler arası etkileşim (interdialect contact) iki veya daha fazla lehçe/diyalekt arasındaki temasın orijinal diyalektlerin hiçbirinde meydana gelmeyen formların gelişmesine yol açtı̆̆ durumlardır. Kırgızlar ile beraber Kırgız dili de tarih boyunca hareket hâlinde olduğu için yukarıda bahsedilen durum fonetik bir hususiyetten çok Kırgızcanın Tarihî ve Çağdaş Türk dil ve diyalektlerle olan etkileşimi sonucu oluşmuş olmalıdır. Bu olgu genel hatlarıyla Yenisey (VII. yy.) döneminden Tiyan-Şan'a olan göç sürecinde (XI.-XVI. yy.lar) Kıpçak alt katmanı (substratum), XVII.-XIX. yüzyıllar arası Çağatay yazı dili alt katmanı, yine aynı yüzyıllara denk gelen ve XX. yy.ın başlarını da kapsayan Kazak, Karakalpak, Tatar, Başkurt, Özbek, Yeni Uygur diyalektlerinin (sonradan yazı dilleri) alt katman teşkil etmesi şeklinde izah edilebilir. 
Johanson (2007: 25-26) Türk dillerinde temel farklılaşmanın bölgesel değişmelere bağlı olduğunu, bu bölgelerde bağımsız, bölgesel tipolojik süreklilikler ortaya çıkmasının yanında birçok Türk dilinde karmaşık alt katmanların da tesirleri olduğunu, bazı dillerin toplumsal-iletişimsel şartlar altında ortaya çıktıklarını belirtir. Değişik türde kurallaşmanın temel sebebi olarak da XII. yy. Moğol istilasını işaret eder. Benzer görüşler yani Çağdaş Türk yazı dillerinin tarihlerindeki tipolojik kopuklukları Dilâçar (1957) tarafından Türk Lehçelerinin Meydana Gelişinde Genel Temayüllerin Koyulaşması ve Körlenmesi adlı çalışmasında da izah edilmiştir.

$\mathrm{Bu}$ çalışmada incelenen sözcükler ile ilgili arkaizm, Tarihî Kıpçakça katmanı, Kıpçak, Karluk yan katmanı vb. görüşler Tarihî ve Çağdaş Türk dillerinden hareketle varılan sonuçlardır. Ancak bu çalışma sonuç kısminda belirtilen görüşlerin tartışılamazlığı iddiasında değildir. Hem Kırgızca hem de diğer Türk dilleri için yapılacak daha detaylı araştırmalar bu konu ve iddiaları güçlendirecek veya onlara farklı açılardan bakmamıza olanak sağlayacaktır.

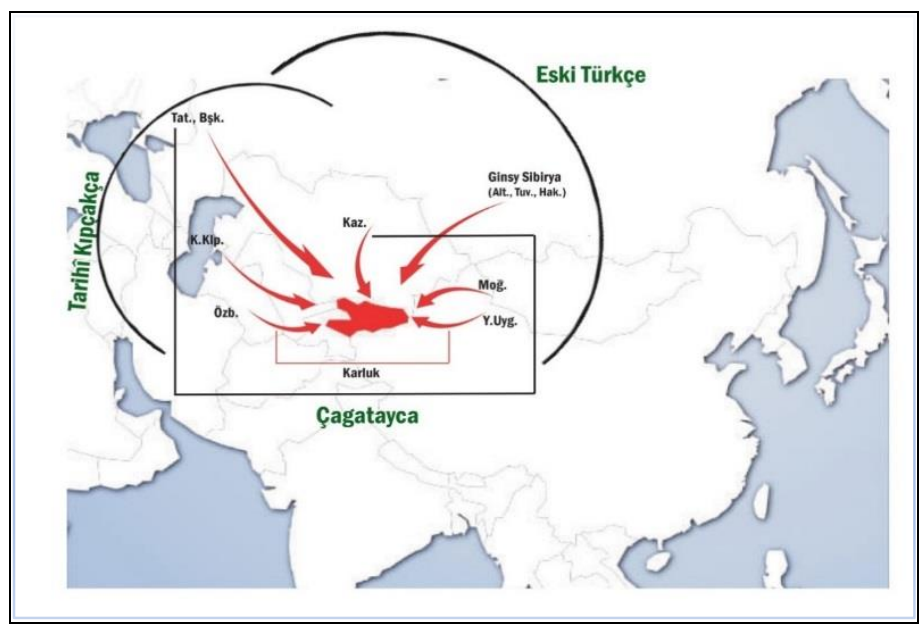

Resim 1: XII. yy. Moğol istilasından sonra Kırgızcadaki alt ve yan katmanlar haritası cıgaç= ET.deki (y)1/ag̉aç biçimi korunmuştur. Arkaizm olarak kabul edilebilir.

bugu= Arkaizm veya Moğolcadan ödünçlemedir.

sogun= Arkaizm

tügül $=$ Arkaizm

ögöy= Kıpçakça katmanı

ügüt= Kıpçak veya Karluk grubu Türk dilleri yan katmanı

tegirmen= Arkaizm veya Kıpçakça katmanı

bögö-, bögöt= Kıpçakça katmanı

ayıl= Moğolcadan tekrar ödünçleme

cıyırma= Kazakça yan katmanı

cıyın= Tarihî Kıpçakça veya Kıpçak grubu Türk dilleri katmanı

cigit= ET.deki yigit biçimine göre arkaizm olarak kabul edilebilir.

\section{Kisaltmalar}

bkz.: Bakınız

Korkut Ata Türkiyat Araştırmaları Dergisi
Uluslararası Türk Dili ve Edebiyatı Araştırmaları Dergisi
The Journal of International Turkish Language \& Literature Research
Sayı 5/ Ağustos 2021


Bodr. İșf.A.: Bodrogligeti, András. On the Turkish Vocabulary of the İsfahan Ananymous

Brock. OGM: Borckelmann, Carl. Osttürkische Grammatik der islamischen Literatursprachen Mittelasiens

Bşk.: Başkurtça:

BV: Baytaratu'1 Vâzıh

Diyal.: Diyalekt

DM: Ed-Dürretü'l-Mudiyye Fi'l-Lügati'tTürkiyye

DTS = Drevnetyurskiye Slovar'

E1: Yenisey Berge anitı

E7: Yenisey Sudji bölgesi anıtı e.a.y.e.: Eylemden ad yapma eki

EDPT = An Etymological Dictionary of Pre-Thriteenth Century Turkish

ESTYa: Etimologiçeskiy Slovar' Tyurskih Yazıkov

ET.: Eski Türkçe

E. Uyg.: Eski Uygurca

Far.: Farsça

GT: Gülistan Tercümesi

Hak.: Hakasça

İM: İrşâdü'1- Mülûk Ve's Selâtîn

Kaz.= Kazakça

KB: Kutadgu Bilig

KFT: Kitâb Fi'l-Fikh Bi'l-Lisâni'tTürkiyye

K.Klp.: Karakalpakça

Kir.: Kirgizca

Kİ: Kitâbü'l-İdrâk Li-Lisâni'l-Etrâk
KK: El- Kavanînü'1-Külliyye Li-Zabti'1Lügati't-Türkiyye

krş.: Karşılaştırınız

KT: Kül Tegin anitı

KWb: Kalmückiches Wörterbuch

MK: Mahmud Kaşgarî

MG: Münyetü'l-Guzât

Moğ.: Moğolca

Orh. T.: Orhon Türkçesi

OT.: Orta Türkçe

OTWF: Old Turkic Word Formation

Özb.: Özbekçe

PT: Proto Türkçe

RH: Kitâb Fî Riyâzâti'1-Hayl

SIGTYaF: $\quad$ Sravnitel'no-Istoriçeskaya Grammatika Tyurskih Yazıkov Fonetika

SIGTYaL: Sravnitel'no-Istoriçeskaya Grammatika Tyurskih Yazıkov Leksika

Sogd.: Sogdca

TA: Kitâb-1 Mecmû-1 Tercümân-1 Türkî ve Acemî ve Mugalî

Tat.: Tatarca

Th S 11: Irk Bitig

TT X: Türkische Turfan Texte $X$

Tuv.: Tuvaca

Türk.: Genel Türkçe

TZ: Et-Tuhfetü'z-Zekiyye Fi'l-Lügati'tTürkiyye

UKD: Uygur Harfli Oğuz Kağan Destanı

VEWT: Versuch eines etymologischen Wörterbuch der Türksprachen

Y. Uyg.: Yeni Uygurca

\section{Kaynakça}

Baskakov, Nikolay A. (1947). Oyrotsko-Russkiy Slovar'. Moskva: GIISN.

Baskakov, Nikolay A. (1953). Haksasko-Rysskiy Slovar'. Moskva: GIINS.

Baskakov, Nikolay A. (1958). Karakalpakso-Russkiy Slovar'. Moskva: GIINS.

Baskakov, Nikolay. A. (1964). Russko-Altayskiy Slovar'. Moskva: Izdatel'stvo Sovyetskaya Entsiklopediya.

Baskakov Nikolay, A. (1969). Vvedenie v izuchenie tyurkskikh yazykov. Moskva: Izdatel'stvo 'Vysshaya Shkola'.

Batmanov, İgor A. (1939). Grammatika Kirgizskogo Yazıka, Vıpusk I. Frunze, Kazan: Kirgizskoye Gasudarstvennoye Izdatel'stvo.

Clauson, Gerard S (1972). An Etymological Dictionary of Pre-Thriteenth Century Turkish. Oxford University Press.

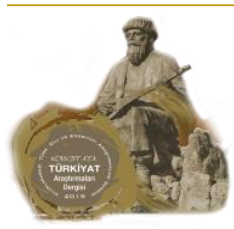


Dilâçar, Agop (1957). Türk Lehçelerinin Meydana Gelişinde Genel Temayüllerin Koyulaşması ve Körlenmesi. (TDAY-Belleten, 5), 83-93.

Doerfer, Gerhard (1967). Türkische und Mongolische Elemente Neupersischen Band II. Wiesbaden.

Eckmann, Janos (1965). Memlük Kıpçakçasının Oğuzcalaşmasına Dair. (TDAY-Belleten 12). 35-41.

Erdal, Marcel (1991). Old Turkic Word Formation: A Functional Approach to the Lexicon, I, II Volumes. Wiesbaden: Harrassowitz.

Gabain, v. Annemarie (1952). Die Natur des Prädikats in den Türksprachen (Türk dillerinde bildiricinin mahiyeti). KsA III. 94-94.

Gabain, v. Annemarie. (2007). Eski Türkçenin Grameri (Çev. Mehmet Akalın). Ankara: TDK Yayınları.

Golden, Peter (1992). An Introduction to the History of the Turkic Peoples. Otto HarrasowitzWiesbaden.

Jankowski, Henryk (2015). Reconstruction of Old Kipchak, Proceedings of the 12th Seoul International Altaistic Conference. (16-19, July). 271-292.

Johanson, Lars (1998). The History of Turkic, The Turkic Languages (Ed. Johanson, L. ve Csató, E.). London: Routledge.

Johanson, Lars (2007). Türk Dil İlişkilerinde Yapısal Etkenler (Çev. Nurettin Demir). Ankara: TDK yayınları.

Karıniyazov, Taşmukhammed N. ve Borovkov, Aleksandr K. (1941). Uzbeksko-Russkiy Slovar'. Taşkent: Izdatel'stvo Uzbekistanskogo Filiala Akademii NAUK SSSR.

Károly, László (2012). History of the intervocalic velars in the Turkic languages, Turkic Languages (Ed. L. Johanson). 16 (2012). 3-24.

Levitskaya, Liliya vd. (2003). Etimologiçeskiy Slovar' Tyurskih Yazıkov (Obşçetyurskiye i mejtyurskiye osnovı na bukvu " $L, M, N, P, S$. Moskva: Izdatel'stvo Vostoçnaya Literatura.

Nadelyayev, Viladimir M., vd. (1969). Drevnetyurskiye Slovar'. Leningrad: NAUKA Leningradskoye Otdeleniye.

Necipoviç, Emir Necip (1995). Yeni Uygur Türkçesi Sözlüğü (Çev. İklil Kurban). Ankara: TDK Yayını.

Nuraliyeva, Kurastırgan N. (2008). Kazakh-English Dictionary. Almatı: Dayk Press

Osmanov, Mukhamet M. (1966). Tatarsko-Russkiy Slovar'. Moskva: Izdatel'stvo Sovyetskaya Entsiklopediya.

Ramstedt, Gustav J. (1924). Die Verneinung in den altaischen Sprachen. (MSFOu). LII 196215.

Ramstedt, Gustav J. (1935). Kalmückisches Wörterbuch. Helsinki: Suomalais-Ugrilainen Seura.

Ramstedt, Gustav J. (1957). Einführung in die Altaische Sprachwissenschaft I Lautlehre. Helsinki: Mémoires de la Société Finno-Ougrienne. No. 104: 1.

Rassadin, Valentin I. (1982). Oçerki po istoricheskoy fonetikiye buryatskogo yazıka. Moskva: Nauk.

Korkut Ata Türkiyat Araştırmaları Dergisi
Uluslararası Türk Dili ve Edebiyatı Araştırmaları Dergisi
The Journal of International Turkish Language E Literature Research
Sayı 5/ Ağustos 2021


Räsänen, Martti (1969). Versuch eines etymologischen Wörterbuch der Türksprachen. Helsinki: Suomalais-Ugrilainen seura.

Serebrennikov, Boris A. ve Gadjieva, Ninel Z. (2011). Türk Yazı Dillerinin Karşılaştırmalı Tarihî Gramer (Çev. Tevfik Hacıyev-Mustafa Öner). Ankara: TDK Yayınları.

Sevortyan, Edvard V. (1974). Etimologiçeskiy Slovar' Tyurskih Yazıkov (Obşçetyurskiye i mejtyurskiye osnovı na glasniye). Moskva: AN SSSR: IN Yazıkoznaniya Nauka.

Sevortyan, Edvard V. (1978). Etimologiçeskiy Slovar' Tyurskih Yazıkov (Obşçetyurskiye i mejtyurskiye osnovı na bukvu "B"). Moskva: AN SSSR: IN Yazıkoznaniya Nauka.

Sevortyan, Edvard (1980). Etimologiçeskiy Slovar' Tyurskih Yazıkov (Obşçetyurskiye i mejtyurskiye osnov na bukvu "V, G, D"). (Red. Ninel Z. Gadjieva). Moskva: AN SSSR: IN Yazıkoznaniya Nauka

Sevortyan, Edvard V. ve Levitskaya, Liliya S. (1989.) Etimologiçeskiy Slovar' Tyurskih Yazıkov (Obşçetyurskiye i mejtyurskiye osnov na bukvu "J, C, Y,"). Moskva: AN SSSR: IN Yazıkoznaniya Nauka.

Subrakova, Ol'ga V. (2006). Hakassko-Russkiy Slovar'. Novosibirsk: Ministerstvo Obrazovaniye i Nauki Resp. Hakasiya.

Tekin, Talat (1989). Türk Dil ve Diyalektlerinin Yeni Bir Tasnifi. (Erdem 13): 141-168.

Tekin, Talat (1995). Türk Dillerinde Birincil Uzun Ünlüler. Ankara: Türk Dilleri Araştırmaları Dizisi- 13.

Tekin, Talat (2003). Orhon Türkçesi Grameri. İstanbul: Türk Dilleri Araştırmaları Dizisi 9.

Tenişev, Ethem R. (1968). Tuvinsko-Russkiy Slovar'. Moskva: Sovyetskaya Entsiklopediya, 646 c. Moskva.

Tenişev Ethem R. (1984). Sravnitel'no-Istoriçeskaya Grammatika Tyurskih Yazıkov Fonetika. Moskva: Akademiya NAUK SSSR.

Tenişev Ethem R. (2001). Sravnitel'no-Istoriçeskaya Grammatika Tyurskih Yazıkov Leksika, Moskva: Rossiyskaya Akademiya Nauk.

Toparlı, Recep vd. (2007). Kıpçak Türkçesi Sözlüğü, Ankara: Türk Dil Kurumu Yayını.

Uraskin, Zinnur G. (1996). Başkirssko-Russkiy Slovar'. Moskva: Izdadetlsvo “Digora”.

Ünlü, Suat (2014). Çağatay Türkçesi Sözlüğü. Konya: Eğitim Yayınevi.

Yılmaz, Emine (2010). Tatarca Ön Ünlülü Sözcüklerde Ünlüler Arası -g- Sesi Üzerine. Türk Dili Araştırmaları Yıllı̆̆ı-Belleten, 58(2), 131-36.

Yudahin, Konstantin K. (1998). Kırgız Sözlüğ̈̈̈ Cilt I, II (Çev. Abdullah Taymas), Ankara: TDK Yayınları.

Yunusaliyev, Bolot M. (2016). Kırgız Dili ve Diyalektleri (Çev. Erhan Taşbaş). Gazi Türkiyat, 19, 241-267. 